\title{
The Level of Difficulty of Teachers in Thematic Learning
}

\author{
Rahmawati Patta ${ }^{1}$, Mauliana Giarni ${ }^{2}$ \\ \{rahmapatta02@gmail.com ${ }^{1}$,maulianagiarni@gmail.com $\left.{ }^{2}\right\}$ \\ ${ }^{1}$ Program Studi Pendidian Guru Sekolah Dasar, Indonesia \\ ${ }^{2}$ Fakultas Ilmu Pendidikan Universitas Negeri Makassar, Indonesia
}

\begin{abstract}
The problem in this study is the difficulty of teachers in thematic learning in elementary schools related to the implementation of the 2013 curriculum. The purpose of the study was to determine the level of difficulty of teachers in thematic learning in Elementary School Cluster IV Tanete Riattang District Bone District. The research approach uses qualitative research with descriptive qualitative research. The research subjects were the teacher or homeroom teacher who taught thematic learning in Elementary School Cluster IV which applied the 2013 curriculum totaling 22 people. Data collection techniques using questionnaires and supporting interviews. Data were analyzed by data reduction, data presentation, and drawing conclusions. The results showed that teachers at the planning stage felt quite difficult and felt the most difficult in the preparation of lesson plans due to changes in the curriculum component. At the implementation stage the teacher found it quite difficult to integrate several maples into one learning accompanied by character planting. At the assessment stage, teachers still experience difficulties, especially in reporting learning outcomes due to lack of understanding and are not familiar with thematic learning assessments.
\end{abstract}

Keyword: Degree of difficulty, Thematic Learning

\section{Introduction}

Education is a human need. Education always changes, develops and improves according to the needs of the times. According to Brubacher that "Education is the reciprocal process of each human person in adjusting himself to nature, friends and the universe"[1]. Meanwhile according to Dahama \& Bhatnagar that "Education is the process of bringing about the desired changes in human behavior"[1].

Education is a dynamic and ongoing process to improve the quality of human resources in ensuring the sustainability of the development of a nation, so that improving the quality of human resources is far more urgent to be realized. Improving the quality of human resources is a reality that must be planned, directed, intensive, effective and efficient. In clause 3 of Law No. 22 of 2003 that education aims to develop the potential of students to become creative, responsible, knowledgeable, independent and pious human beings with good morals. From the previous description, it was concluded that education is a reciprocal process that leads to change to develop one's abilities and behavior.

One dimension that cannot be separated from education is curriculum policy. According to Puskur that the curriculum is the main element in making a significant contribution to realize the process of developing the quality of human resources. The curriculum is the heart of the 
world of education [2]. Therefore, future curricula need to be designed and refined to improve the quality of education nationally and improve the quality of Indonesian human resources. In Law No. 20 of 2003, the curriculum is a set of plans and arrangements regarding the objectives, content and learning materials as well as the methods used to guide the implementation of learning activities to achieve the objectives of national education.

The curriculum in Indonesia has undergone many changes starting from the 1947 lesson plans to the Education Unit Level Curriculum (KTSP) which then underwent refinement with the 2013 Curriculum which of course had been planned carefully. A fairness if the curriculum changes frequently because the curriculum must be in accordance with the needs and developments that exist for the advancement of Indonesian education.

The 2013 curriculum itself was designed as an alternative to improving the face of Indonesian education. The 2013 curriculum is based on the culture and character of the Indonesian nation which is civilization based and competency based. Because this curriculum is more emphasized on character education.

A distinctive feature of the 2013 curriculum in elementary schools is the thematic learning system in all classes. The 2013 curriculum is thematic-integrative in nature, taking subjects based on themes by combining several lessons into one [3].

"Thematic learning is learning that integrates various competencies from various subjects into various themes"[4]. "Thematic learning is an approach to learning that intentionally links several aspects both in intramata and between subjects" [5]. Thematic learning aims to make learning take place meaningfully. Thematic learning is expected to be able to activate students in class. Thematic learning places more emphasis on student involvement in active learning processes. This learning concept students are expected to learn by doing something (learning by doing). So with thematic learning students can get hands-on experience.

Applying the concept of thematic learning is certainly not free from the role of a teacher. All change efforts in education, both curriculum updates and the latest learning designs depend on the expertise of a teacher.

Related to the implementation of thematic learning in the 2013 curriculum, of course the teacher adjusts the implementation of their tasks. It is said that the teacher is very important in determining the success of the 2013 curriculum. This indicates that the success of the curriculum change depends on the willingness and ability of the teacher to implement the 2013 curriculum [6]. Thematic learning naturally expects teachers to develop more creativity in developing learning activities. Can deal with students of varying abilities, material or teaching material, compile indicators that will be achieved by students and make an assessment of the achievements of each student in this thematic learning.

Thematic learning in the 2013 curriculum has been designed so well. So that teachers are required to be ready in applying thematic learning in schools with socialization and training. By conducting socialization and training on thematic learning as an application of the 2013 curriculum, teachers can master and apply thematic learning.

Based on the surrounding phenomena that occur that every teacher has a complaint in the implementation of the 2013 curriculum. Likewise with some previous research that they have difficulty in implementing thematic learning because it is influenced by several factors, such as knowledge of thematic learning concepts, low interest and willingness in understand the concept of thematic learning [7]. Teacher understanding in the 2013 curriculum is still not comprehensive and is constrained in integrating subjects in thematic learning [2]. Based on observations in one of the Tanete Riattang District schools, the teacher complained of the difficulty of making thematic lesson plans and the difficulty in recapitulating student scores. Teachers also have difficulty in determining learning resources and learning media so that 
learning is not active and is only centered on the teacher. In addition, the teacher also complained of difficulties in making question instruments so that the assessment of students was less than optimal. The teacher feels the assessment of thematic learning is too complicated because there are many aspects that must be assessed [8] in addition to the assessment of knowledge as well as the attitude and spiritual assessment as a form of inculcation of student character. Based on the description that has been stated, the purpose of this study is to determine the level of difficulty of teachers in thematic learning in Elementary School Group IV Tanete Riattang District Bone District.

\section{Methods}

The approach used by researchers is qualitative research and the type of research used is descriptive research. The presence of researchers at the research location is the main instrument. The data source of this research is the teacher or homeroom teacher who teaches thematic learning in Elementary School Cluster IV Tanete Riattang District, Bone Regency. Data collection techniques were carried out by giving questionnaires and supporting interviews. Data analysis uses data reduction analysis, data presentation, and conclusion drawing. Indicators in the thematic learning in this study consisted of planning (compiling syllabus and lesson plans), implementing learning and assessment (preparation of instruments and assessment reports).

\section{Results And Discussion}

This research was carried out in elementary school Group IV Tanete Riattang District Bone District with a total of six schools. Teachers are selected from each school in Cluster IV. There are 22 teachers teaching thematic learning. All teachers were given a questionnaire on the level of difficulty in thematic learning.

\section{Planning phase of thematic learning}

Table 3.1. Percentage of Teachers at Difficulty Level of Thematic Learning Planning Steps

\begin{tabular}{|c|c|c|c|c|c|}
\hline \multirow[b]{2}{*}{ No } & \multirow[b]{2}{*}{ Indicator } & \multicolumn{4}{|c|}{ Difficulty Level } \\
\hline & & Not Hard & $\begin{array}{c}\text { Quite } \\
\text { difficult }\end{array}$ & Difficult & $\begin{array}{l}\text { Very } \\
\text { Hard }\end{array}$ \\
\hline 1 & Compiling Syllabus & 0 & $68 \%$ & $32 \%$ & 0 \\
\hline 2 & Compiling RPP & $4,5 \%$ & $54,5 \%$ & $41 \%$ & 0 \\
\hline 3 & formulating learning objectives & $9 \%$ & $68 \%$ & $23 \%$ & 0 \\
\hline 4 & $\begin{array}{c}\text { Determine the subject matter in accordance with } \\
\text { the learning objectives }\end{array}$ & $9 \%$ & $73 \%$ & $18 \%$ & 0 \\
\hline 5 & Determine learning methods & $14 \%$ & $54 \%$ & $32 \%$ & 0 \\
\hline 6 & Making learning media & $14 \%$ & $64 \%$ & $23 \%$ & 0 \\
\hline 7 & Arrange the steps of the activity & $4,5 \%$ & $82 \%$ & $9 \%$ & $4,5 \%$ \\
\hline 8 & $\begin{array}{l}\text { Formulate time allocation in accordance with the } \\
\text { steps of the activity }\end{array}$ & $14 \%$ & $64 \%$ & $18 \%$ & $4 \%$ \\
\hline
\end{tabular}




$\begin{array}{lllll}\text { Planning Steps } & 9 \% & 66 \% & 24 \% & 1 \%\end{array}$

In general, the highest percentage of teachers at the difficulty level of the planning stage is quite difficult. Then the difficulty level of the planning stage is quite difficult. And looking at the results of the average questionnaire for each indicator, the highest average result is indicator number 2 regarding the preparation of lesson plans.

\section{Implementation phase of thematic Learning}

Table 3.2. Percentage of Number of Teachers at Difficulty Level of Thematic Learning Implementation Steps

\begin{tabular}{|c|c|c|c|c|c|}
\hline \multirow[b]{2}{*}{ No } & \multirow[b]{2}{*}{ Indicator } & \multicolumn{4}{|c|}{ Difficulty Level } \\
\hline & & Not Hard & $\begin{array}{c}\text { Quite } \\
\text { Difficult }\end{array}$ & Difficult & $\begin{array}{l}\text { Very } \\
\text { hard }\end{array}$ \\
\hline 9 & Apperception in the initial activity & $36 \%$ & $64 \%$ & 0 & 0 \\
\hline 10 & Delivering Material & $9 \%$ & $77 \%$ & $14 \%$ & 0 \\
\hline 11 & Embed character & $5 \%$ & $45 \%$ & $50 \%$ & 0 \\
\hline 12 & Implement the learning method & 0 & $68 \%$ & $32 \%$ & 0 \\
\hline 13 & Use Media & $4 \%$ & $73 \%$ & $23 \%$ & 0 \\
\hline 14 & Use learning resource & $18 \%$ & $68 \%$ & $5 \%$ & $9 \%$ \\
\hline 15 & carry out the steps of the activity & $4 \%$ & $73 \%$ & $23 \%$ & 0 \\
\hline & Implementation Steps & $11 \%$ & $67 \%$ & $21 \%$ & $1 \%$ \\
\hline
\end{tabular}

In general, the highest percentage of teachers at the difficulty level of the implementation phase is quite difficult. Then the difficulty level of the implementation stage is quite difficult. And looking at the results of the average questionnaire for each indicator, the highest average result is indicator number 11 regarding the inculcation of characters in thematic learning.

\section{Assessment phase of thematic learning}

Table 3.3. Percentage of Teachers at Difficulty Level of Thematic Learning Assessment Steps

\begin{tabular}{|c|c|c|c|c|c|}
\hline \multirow[b]{2}{*}{ No } & \multirow[b]{2}{*}{ Indicator } & \multicolumn{4}{|c|}{ Difficulty Level } \\
\hline & & Not Hard & $\begin{array}{c}\text { Quite } \\
\text { difficult }\end{array}$ & Difficult & $\begin{array}{l}\text { Very } \\
\text { Hard }\end{array}$ \\
\hline 16 & Make a grading grid & $18 \%$ & $45 \%$ & $27 \%$ & $9 \%$ \\
\hline 17 & Make a multiple choice instrument & $23 \%$ & $45 \%$ & $27 \%$ & $5 \%$ \\
\hline 18 & Making instrument stuffing & $18 \%$ & $50 \%$ & $27 \%$ & $5 \%$ \\
\hline 19 & Making instruments about essays & $4,5 \%$ & $64 \%$ & $27 \%$ & $4,5 \%$ \\
\hline
\end{tabular}




\begin{tabular}{cccccc}
\hline 20 & Making attitude assessment instruments & $5 \%$ & $45 \%$ & $50 \%$ & 0 \\
\hline 21 & Making performance appraisal instruments & $9 \%$ & $59 \%$ & $32 \%$ & 0 \\
\hline 22 & Make scoring guideline & $4,5 \%$ & $59 \%$ & $32 \%$ & $4,5 \%$ \\
\hline 23 & Score summary & $4 \%$ & $59 \%$ & $23 \%$ & $14 \%$ \\
\hline 24 & report learning outcomes & $5 \%$ & $41 \%$ & $36 \%$ & $18 \%$ \\
\hline & Assessments Steps & $10 \%$ & $52 \%$ & $31 \%$ & $7 \%$ \\
\hline
\end{tabular}

In general, the highest percentage of teachers at the difficulty level of the assessment stage is quite difficult. Then the level of difficulty of the assessment stage is quite difficult. And looking at the results of the average questionnaire for each indicator, the highest average result is indicator number 24 regarding reporting learning outcomes on thematic learning.

\section{Discussion}

Thematic learning is integrated learning that makes the theme as a reference in linking concepts and materials from several subjects [5]. Thematic learning is learning that concepts from various subjects are integrated into one theme to get a more meaningful experience. Regarding the results of the study, it was found that the level of difficulty at each stage of thematic learning was quite difficult.

At the planning stage of thematic learning, it was found that the highest percentage of teachers found it quite difficult. As it is known that the planning stage becomes a reference in carrying out the steps of the thematic learning activities. Although it is said that "good learning planning is not a guarantee of being able to create effective learning. But effective learning will not be realized without a good planning "[9].

The highest average indicator at the planning stage is the preparation of thematic lesson plans with $4.5 \%$ of teachers feeling not difficult, $54.5 \%$ of teachers feeling quite difficult and $41 \%$ of teachers feeling difficult. Then the preparation of lesson plans is an indicator with a fairly difficult level. The results of this study are supported by one of the results of previous studies that "as many as $33 \%$ of respondents stated that the preparation of the lesson plan is not too difficult for them. The lesson plan is simply to reduce and develop from the syllabus" [10]. One of the statements by the teacher with the initials NE "is clearly obstructed in making lesson plans, if the syllabus component changes, the lesson plans change too." So compiling the lesson plan is quite difficult to do because the steps in the lesson plan must be more detailed than the syllabus. in accordance with the statement that the lesson plan is a learning plan that is developed in detail from a particular subject matter or theme that refers to the syllabus [4].

An indicator with a high average is also the preparation of a syllabus with $68 \%$ of teachers feeling quite difficult and $32 \%$ of teachers feeling difficult. Then the preparation of the syllabus is an indicator with a fairly difficult level. The results of this study are supported by the results that "compiling a syllabus and compiling an assessment are considered very difficult for each step by $4 \%$ of 24 respondents" [10]. Supported by the teacher's initial NE statement "it is difficult because there are changes in the components so I have to learn more this syllabus arrangement". So this data is quite difficult because of changes in the syllabus component of the 2013 curriculum. Teachers have not been able to adapt to changes in the 
2013 curriculum. Contrary to the results of previous research that the readiness of teachers in welcoming the 2013 curriculum from the Emotive-Attitudinal aspects (enthusiastic, responsible, willingness to adapt, and independence) in Yogyakarta City, Sleman Regency, Kulon Progo Regency, and Gunungkidul Regency in the very ready category and in Bantul in the ready category [11].

At the implementation stage of thematic learning, it was found that the highest percentage was quite difficult. The implementation phase is the most important stage in learning. At this stage there are core activities. "Core activities are learning processes to achieve goals, which are carried out interactively, inspiringly, are fun, challenging, and motivate students to be active" [12]. At this stage the teacher conveys subject matter to achieve the learning objectives.

The indicator with the highest average at the implementation stage is character planting with $5 \%$ of teachers feeling not difficult, $45 \%$ of teachers feeling quite difficult, $50 \%$ of teachers feeling difficult with an average value of the questionnaire results 2.5 . Then this indicator lies at a difficult level. Based on the statement of the teacher initials NE "yes it's difficult indeed this is willing to instill the character of every child with different character not to mention the influence of technology now. But if I actually rarely pay attention to it, I want to instill the character of children. I still do not understand the meaning of character education. The teacher does not understand character education and neglects the inculcation of character in thematic learning. Of course this is not in accordance with the characteristics of the 2013 curriculum that is the whole learning process is directed to achieve religious core competencies and social core competencies [13] where all of the learning process must be to inculcate attitudes or characters in students.

At the thematic learning assessment stage, it was found that the highest percentage was quite difficult. Assessment is one part of learning that is intended to measure the ability of students to follow the learning process [12]. So the assessment must be carried out as well as possible.

The indicator with the highest average at the assessment stage is reporting learning outcomes with $5 \%$ of teachers feeling not difficult, $41 \%$ of teachers feeling quite difficult, $36 \%$ of teachers feeling difficult and $18 \%$ of teachers feeling very difficult. Based on one of the statements of the teacher with the initials NE "it is a report card for the 2013 curriculum we use the application. If we want to write our hands too overwhelmed. Using the application is also quite difficult if you don't understand the package. Because I'm also confused using that application ". Teachers find it quite difficult because they lack mastering the use of the 2013 curriculum report application. This data is supported by the results of research that that $5 \%$ of the 2013 curriculum constraints coming from teachers is the lack of mastery of IT [2].

The indicator with the highest average is also recapitulating scores with $4 \%$ of teachers feeling not difficult, $59 \%$ of teachers feeling quite difficult, $23 \%$ of teachers feeling difficult and $14 \%$ of teachers feeling very difficult. Then this indicator lies at a pretty difficult level. Based on one of the statements of the teacher with the initials IR "this assessment is difficult every week to work". Likewise with other statements from the teacher with the initials SS "this recap of grades is quite complicated. Tired because a lot of KDs must be separated according to their subjects ". In addition, another statement from the teacher with the initials $\mathrm{NE}$ "this would like to recapitulate the value of the children must spend a lot of time each week also want to do. These grades are also recapitulated by each subject while the thematic material is combined with the subjects. So we want to separate the values of each subject ". Based on these statements, recapitulation is quite difficult because of the many scores that must be processed. This data is supported by the results of previous studies that teachers feel 
the assessment of thematic learning is too complicated because there are many aspects that must be assessed [8].

\section{Conclusion}

Teachers on thematic learning experience some difficulties in its application. In the planning stage felt quite difficult and felt most difficult in the preparation of lesson plans caused by changes in the curriculum component. At the implementation stage the teacher felt quite difficult and the most difficult inculcation of characters for the teacher was at the implementation stage because he did not yet understand the concept of thematic learning implementation. Teachers at the assessment stage find it quite difficult and find it most difficult when reporting learning outcomes because the teacher lacks knowledge and is not yet accustomed to thematic learning assessments. And the level of difficulty of the teacher in thematic learning is quite difficult. The high level of difficulty is caused by the lack of knowledge about thematic learning concepts, the lack of creativity of teachers in overcoming obstacles, and the lack of mastery of IT as well as the lack of thematic learning implementation exercises so as to maximize the socialization of thematic learning concepts by conducting training on applying thematic learning by utilizing KKG forums for mutual learn about thematic learning.

\section{Acknowledgements}

The authors thank the rector of the Makassar state university, head of the PGSD study program, for the support given in writing this article, PGSD students who assisted in the preparation, the district bone education office and school principal and teachers at Elementary School Cluster IV Tanete Riattang District Bone.

\section{References}

[1] R. Ahmadi, Pengantar Pendidikan: Azas dan Filsafat Pendidikan. Yogyakarta: ArRuzz Media, 2014.

[2] R. Krissandi, Apri Damai Sagita, "Kendala Guru Sekolah Dasar dalam Implementasi Kurikulum 2013,” J. Cakrawala Pendidik., vol. XXXIV (3), 2015.

[3] R. Kristiantari, "Analisis Kesiapan Guru Sekolah Dasar dalam Mengimplementasikan Pembelajaran Tematik Integratif Menyongsong Kurikulum 2013," J. Pendidik. Indones., vol. 3(2), pp. 460-469, 2014.

[4] M. Shobirin, Konsep dan Implementasi Kurikulum 2013 di Sekolah Dasar. Yogyakarta: Deepublish, 2016.

[5] A. Majid, Pembelajaran Tematik terpadu. Bandung: Remaja Rosdakarya, 2014.

[6] J. Suprihatiningrum, Guru Profesional: Pedoman Kinerja, Kualifikasi dan Kompetensi Guru. Yogyakarta: Ar-Ruzz Media, 2014.

[7] and H. Y. Prastianingsih, Dwi Ramadani, Berchah Pitoewas, "Analisis Kesulitan Guru dalam Pembelajaran Tematik di SD Negeri 3 Haji Pemanggilan Kabupaten Lampung Tengah Tahun Pelajaran 2012/2013," J. Penelit., 2013.

[8] N. Enggarwati, "Kesulitan Guru SD Neger Glagah dalam Mengimplementasikan Penilaian Autentik pada Kurikulum 2013," J. Pendidik. Guru Sekol. Dasar, vol. 4(12), 2015. 
[9] A. Prastowo, Rencana Pelaksanaan Pembelajaran (RPP) Tematik Terpadu Implementasi Kurikulum 2013 SD/MI. Jakarta: Kencana, 2017.

[10] D. Gularso, "Analisis Kesulitan dalam Perencanaan Pembelajaran Tematik di Sekolah Dasar,” J. JPSD, vol. 3(2), p. 62, 2017.

[11] M. N. Wangid, A. Mustadi, V. Y. Erviana, and S. Arifin, "KESIAPAN GURU SD DALAM PELAKSANAAN PEMBELAJARAN TEMATIK-INTEGRATIF PADA KURIKULUM 2013 DI DIY," J. Prima Edukasia, 2014.

[12] M. Fadillah, Implementasi Kurikulum 2013 dalam Pembelajaran SD/MI, SMP/MTs, SMA/MA. Yogyakarta: Ar-Ruzz Media, 2014.

[13] J. Musfah, Manajemen Pendidikan: Teori, Kebijakan dan Praktik. Jakarta: Kencana, 2015. 